\title{
COVID-19 da Sitokinler ve COVİD- 19 Tedavisinde Kullanılan İlaçlar Arasında Potansiyel İlaç Etkileşimleri
}

\section{Potential Interactions between Increased Cytokines in COVID-19 and Drugs Used to Treat COVID-19}

\author{
Tülün Öztürk ${ }^{1 *}$, Tuğba Gürpınar², Canet İncir Balaban ${ }^{3}$, Yeşim Tunçok ${ }^{3}$ \\ ${ }^{1}$ Manisa Celal Bayar University, Faculty of Medicine, Department of Anesthesiology and Reanimation, Manisa, \\ Turkey \\ ${ }^{2}$ Manisa Celal Bayar University, Faculty of Medicine, Department of Medical Pharmachology, Manisa, Turkey \\ ${ }^{3}$ Dokuz Eylul University, Faculty of Medicine, Department of Medical Pharmachology, İzmir, Turkey \\ e-mail: ozturktulun@yahoo.com, tugbagurpinar@gmail.com, canetbalaban@ hotmail.com, \\ yesim.tuncok@gmail.com \\ ORCID: 0000-0003-1693-6674 \\ ORCID: 0000-0002-4787-8561 \\ ORCID: 0000-0002-6298-8419 \\ ORCID: 0000-0002-4049-336X \\ *Sorumlu yazar/ Corresponding Author: Tülün Öztürk \\ Gönderim Tarihi / Received: 02.02.2021 \\ Kabul Tarihi / Accepted: 24.02.2021 \\ DOI: $10.34087 /$ cbusbed.873082
}

\section{Öz}

COVID-19 enfeksiyonu sırasında virus ve konakçı hücre etkileşimleri çok güçlü immun mediyatörlerin akut üretimine yol açmaktadır. Ağır klinik durum çoğunlukla virüsün indüklediği makrofaj ve granülositlerden aşırı inflammatuar sitokin üretimine bağlıdır. Enfeksiyöz ve inflammatuar koşullar altında, klinik ve deneysel çalışmalar göstermiştir ki, ilaç metabolizmasından sorumlu olan karaciğer ve karaciğer dışı sitokrom P450 (CYP) enzimleri ve taşıyıcı proteinler pek çok sitokinler tarafından spesifik olarak regüle edilmektedirler. Sitokinler tarafından bu enzimlerin downregülasyonu, plazma ilaç düzeylerinde yükselmeye neden olabilir ve/veya advers ilaç reaksiyonlarına ve/veya toksisiteye yol açabilir. İnfeksiyon ve inflammasyon koşullarında oluşan sitokin-ilaç etkileşimleri bilgilerimiz temelinde, bu derlemenin amacı, COVID-19 hastalarını tedavi etmek için tek başına veya kombinasyonla kullanılan ilaçların metabolizmaları üzerine kontrolsüz sitokin salınımının etkisini araştırmak ve advers ilaç etkilerine neden olabilecek ilaç- ilaç etkileşimlerini öngörmektir.

Anahtar kelimeler: COVID-19, Sitokin - ilaç etkileşimleri, Sitokrom p450.

During COVID-19 infection, virus and host cell interactions lead to the acute production of very strong immune mediators. The clinical status caused by damage throughout the body is mostly due to excessive pro-inflammatory cytokine production from virus-induced macrophages and granulocytes. Under infectious and inflammatory conditions, clinical and experimental studies have demonstrated that hepatic and extrahepatic cytochrome P450 (CYP) enzymes and carrier proteins responsible for drug metabolism are specifically regulated by many cytokines. Downregulation of these enzymes by cytokines can cause an elevation in plasma drug levels and/or lead to adverse drug reactions and/or toxicity. Based on the knowledge of cytokine-drug interactions occurring in the infection and inflammation stage, the aim of this review was to ascertain the influence of uncontrolled cytokine release on the metabolism of drugs used alone or in combination to treat COVID-19 patients and predict drug-drug interactions causing adverse effects.

Keywords: Cytokine-drug interactions, cytochrome p450, COVID-19

\section{Introduction}

Severe acute respiratory syndrome coronavirus-2 (SARS-CoV-2), a novel type of coronavirus, has caused a global pandemic called coronavirus disease 19 (COVID-19) by the World Health Organization (WHO) that has an extensive impact [1]. The disease has been 
limited by social and/or personal protection methods such as quarantine and personal hygiene. COVID-19 patients are treated with supportive and targeted strategies. To date, based on the evidence, there is no known specific COVID-19 drug with proven efficacy and safety. Anti-viral, immunomodulatory, antiinflammatory, and cytokine-blocking drugs are used in combination under drug repurposing concept [2]. The efficacy and safety of these drugs continue to be explored by many global human clinical trials. Vaccine development studies against COVID-19 are ongoing [3]. The virus and host cell interactions during COVID-19 lead to the acute production of very strong immune mediators. The clinical status caused by the damage throughout the body has mostly due to excessive proinflammatory cytokine production from the virusinduced macrophage and granulocytes. The level of proinflammatory cytokines and the number of immune cell subsets are involved in determining the severity of clinical status. In those severely infected with SARSCOV-2, acute respiratory distress syndrome (ARDS) can develop due to cytokine storm [4].

Regarding cytokine profiles, serological markers, and clinical symptoms, COVID-19 is similar to secondary hemophagocytic lymphohistiocytosis (sHLH), which is frequently triggered by viral infections [5,7]. Severe clinical status is defined as macrophage activation syndrome (MAS) or sHLH and is the result of "cytokine storm" that causes severe tissue damage [6,9]. COVID19 patients have high levels of circulating TNF- $\alpha$, IL- $1 \beta$, IL-1Ra, sIL-2R $\alpha$, IL-6, IL-10, IL-17, IL-18, and IFN- $\gamma$ $[9,10]$.

Under infectious and inflammatory conditions, clinical and experimental studies have shown that hepatic and extrahepatic cytochrome P450 (CYP) enzymes and carrier proteins responsible for drug metabolism are specifically regulated by many cytokines [11-22]. Downregulation of these enzymes by cytokines can cause an elevation in plasma drug levels and/or can lead to adverse drug reactions and/or toxicity [15,18-22]. Many drug combinations are used to treat COVID-19 patients with increased uncontrollable cytokine responses, who are hemodynamically unstable, and/or require intensive care. In this infection environment, it is not yet known how the drug responses are affected due to changes in the drugs' pharmacokinetics and pharmacodynamics. Regarding the decrease in hepatic extraction and/or activity of CYP enzymes due to cytokine release, when treating COVID-19 in clinical practice, drug-drug interactions and drug-masked adverse drug reactions will increase the frequency of possible patient harm. Based on the knowledge of cytokine-drug interactions occurring in the infection and inflammation stage, the aims of this review are to ascertain the influence of uncontrolled cytokine release on the metabolism of drugs used alone or in combination to treat COVID-19 patients and predict the drug-drug interactions causing adverse effects.

\section{Pathogenesis of COVID-19, Clinical Course and Treatment Protocols}

The clinical course of COVID-19 consists of responses that start with the entry of the virus into the body and are triggered by the virus itself, and then the host's immune and inflammatory responses. Siddigi et al [23] divided the disease into 3 stages with increasing severity (Figure 1). In the early infection stage (Stage I), the incubation stage when the virus is hosted and proliferates in the respiratory tract, mild or non-specific findings prevail. Similar to other SARS-CoV viruses, SARS-CoV-2 binds to angiotensin-converting enzyme-2 (ACE2) receptors and enters human cells [24]. These receptors are most commonly found in the human lungs, intestinal epithelium, and vascular endothelium. Since the virus is inhaled in droplets, its affinity to the lungs is higher than the other organsDuring this period, COVID-19 patients are treated to relieve their symptoms. Drugs that prevent viral entry to the cell (chloroquine/hydroxychloroquine and camostat) and anti-viral drugs that block viral replication (favipiravir, remdesivir, ritonavir/lopinavir, darunabir/cobistat, and umifenovir) administered during this period can shorten the duration of symptoms, reduce transmission, and prevent disease progression [25-31]. Many patients on these treatments recover, whereas in cases where treatment is not possible or fails, second stage (Stage II) symptoms develop. The second stage includes viral pneumonia in which the virus multiplies and localized inflammation develops. This may be accompanied by hypoxia $\left(\mathrm{PaO}_{2} / \mathrm{FiO}_{2}<300 \mathrm{~mm} \mathrm{Hg}\right)$ with high (type $\mathrm{H}$ hypoxia) or low compliance (type $\mathrm{L}$ hypoxia) [32]. Bilateral infiltrates or ground-glass opacities are typical in lung imaging studies $[5,32]$. This stage requires close observation of hospitalized patients. Systemic inflammation markers begin to increase. At this stage, supportive therapy and anti-cytokine and anti-viral drugs are administered [28-36]. If there is no clear hypoxia at this stage, corticosteroids are not recommended. If hypoxia and refractory sepsis occur, anti-inflammatory drug treatment including low-dose systemic corticosteroids are applied. At this stage, hypoxia may require oxygen support and mechanical ventilation. However, recent reports showed that earlier administration of corticosteroids reduced the need for intubation and mortality [37,38]. The last stage (Stage III) involves systemic hyperinflammation. CD4, CD8, and regulator $\mathrm{T}$ cell numbers decrease and biomarkers such as IL-2, IL-6, IL-7, granulocyte colony-stimulating factor, macrophage inflammatory protein 1-a, tumor necrosis factor-a, C-reactive protein, ferritin, and Ddimers increase significantly [23,24]. Troponin and Nterminal pro B-type natriuretic peptides increase. Secondary hemophagocytic lymphohistiocytosis occurs [4]. Multiple organ failure (shock, vasoplegia, respiratory failure, and even cardiopulmonary collapse and myocarditis) progresses. At this stage, immunomodulatory agents, corticosteroids, and cytokine inhibitors such as tocilizumab (IL-6 inhibitor) or 


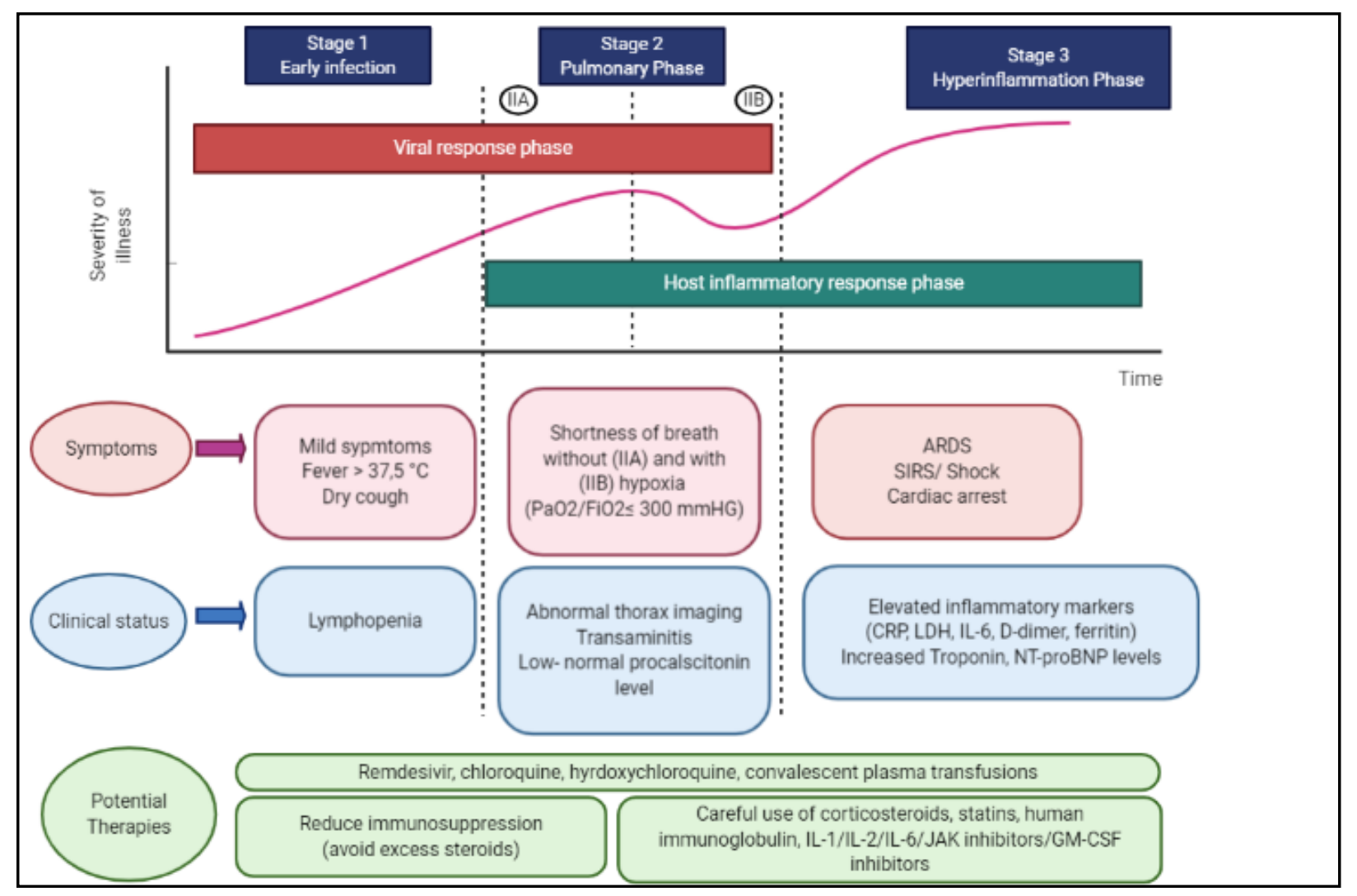

Figure 1. Clinical course of COVID-19 and the drugs used for the treatment.

anakinra (IL-1 receptor antagonist) are used to regulate systemic inflammation to prevent multiple organ failure [5,33-42].

Current COVID-19 treatment modalities are not based on the evidence, but on the results of a limited number of observational studies or strong expert opinions. In the context of drug repurposing, in addition to the known drug indications, the possible efficacy of COVID-19 treatment has been investigated by in vitro and in vivo experimental studies and human clinical trials. According to the COVID-19 Treatment Guidelines by the National Institutes of Health and the Turkish Ministry of Health, no specific treatment is recommended for suspected asymptomatic COVID-19 cases [33, 34, respectively]. Evidence-based or opposite recommendations for anti-viral or immunomodulatory therapy in patients with mild-moderate to severe clinical course and require intensive care are not yet available $[2,33]$.

In the majority of clinical studies currently conducted worldwide, high-dose or low-dose chloroquine/hydroxychloroquine (CQ/HCQ) are used in most cases with mild and moderate symptoms that do not require intensive care [clinicaltrials.gov, accessed December 27, 2020]. In these studies, CQ/HCQ is administered alone, together with azithromycin and/or anti-viral agents (lopinavir/ritonavir, darunavir/cobicistat, favipiravir, or remdesivir) failure [24-31].
Observational and interventional clinical studies using cytokine inhibitors (anakinra or tocilizumab) and specific immunoglobulins dominate in patients requiring intensive care and are aggravated by the host's excessive cytokine response. Interferon-alpha, gamma, and corticosteroids are other drugs used [35, 39-42]. Although the primary endpoint in none of these studies was drug interactions, observational studies with $\mathrm{Q} / \mathrm{HQ}$ alone or azithromycin found that lethal ventricular arrhythmia and mortality rates were higher in these patients than those who did not take this medication [4345].

\section{Cytokines in The Inflammatory Response and Their Influence on Cytochrome P450 Enzymes}

Cytokines are proteins that trigger specific controlled responses to inflammation and infection in the body and are not secreted under normal conditions. They are secreted from stimulated monocytes, macrophages, $\mathrm{T}$ cells, mast cells, and non-hematopoietic cells such as adipocytes, fibroblasts, hepatocytes, epithelial cells, and chondrocytes [46]. They are involved in changes in drug pharmacokinetics and pharmacodynamics by activating intracellular signaling systems [47, 48]. They demonstrate the same effect not only in the liver but also in the intestine, kidneys, immune system, and cancer cells [47-49].

The liver is the key drug metabolism organ. Disorders in the activity or expression of drug-metabolizing enzymes 
alter hepatic clearance. Although cytochrome P450 (CYP) enzymes have approximately 50 subtypes, CYP1A2, CYP2C9, CYP2C19, CYP2D6, CYP3A4, CYP3A5, CYP2B6, and CYP2E1 subtypes are mainly responsible for the metabolism of $90 \%$ of drugs [27, 50, 51].

In 1978, Chang et al [52], for the first time reported that drug pharmacokinetics changed in humans under inflammation and infection conditions, and this change was later attributed to the effects of cytokines on hepatic CYP enzymes [53]. Studies on how cytokines affect different CYP enzymes are primarily in vivo experiments or in vitro cell cultures with lipopolysaccharide (LPS) and experimental models including different inflammatory mechanisms created by the administration of active virus or direct cytokines [11,52-55]. These interactions in humans have mostly been studied in patients with chronic inflammation [13,21,56,57]. In these studies, IL-6, IL-1, TNF, and IFN downregulate mRNA or reduce the activity of essential CYP enzymes. Zhou $\mathrm{J}$ and $\mathrm{Li}$ F [55], summarized eleven studies involving the effects of cytokines on different CYPs in primary cultured human hepatocytes. The effects of cytokines on CYP enzymes in human hepatocytes were investigated in an extensive in vitro study by Aetkins et al [14]. In this study, IL-6 decreased CYP3A4 mRNA by over $90 \%$ in human hepatocytes. IL-6 and TGF downregulated CYP2C9 and 2C19 mRNAs but did not affect TNF, IL-1, IFN, or LPS. IL-6 and IFN downregulated both protein and RNA of CYP2B6, but TNF did not affect IL-1, IFN, or LPS [4]. Tumor necrosis factor, TGF, and IL-1 showed a very low effect on CYP2B6 mRNA, but a significant downregulation of CYP2B6 protein. TGF downregulated CYP2Cs and CYP3A4 at the mRNA level, but CYP2B6 mRNA was not affected. IL-1 did not affect CYP2C9 18 or 19, but decreased CYP2C8 and CYP3A4 mRNA expression by $75 \%$ and $95 \%$, respectively. Cytokines minimally affected CYP2C18 expression in the liver. The same study reported that human CYP450 enzyme activity was independently regulated in infection and inflammation [14]. A decrease in CYPs 2C11, 2C12, 1A1, 2E1, and $3 \mathrm{~A} 2$ protein and mRNA levels was observed after administration of IL-6, IL-1, or TNF5 [4]. Interferongamma was released from $\mathrm{T}$ cells in response to LPS or antigen stimulation. In rat hepatocyte cultures, IF gamma did not affect CYP2C11 at the mRNA or protein levels but changed CYP3A expression [14]. while downregulating CYP2C8 mRNA and CYP2C9 protein in human hepatocytes [58]. IFN downregulated CYP1A2, 2A6, 2B6, and 3A4 activities in human hepatocytes as well as mRNA and the protein expression of CYP1A2 and 3A4 [4]. Dickmann et al [19]. reported that IL-6 reduced $\mathrm{CYP} 2 \mathrm{C} 8, \mathrm{CYP} 2 \mathrm{C}$, CYP2C19, and CYP3A4 mRNA expression and blocked CYP1A2 and CYP3A4 activity in human hepatocyte cultures. Anti-IL-6 monoclonal antibody resolved this suppression or partially blocked it [19].
Morgan et al, [13] screened the clinical drug-disease and drug-drug relationship for the regulation of CYP450 enzymes related to inflammation. The severity of the inflammatory response in chronic human inflammatory diseases is lower than that of the acute inflammatory response in infection and tissue damage because the cells adapt to stress and dysfunction [13]. The downregulating effects of cytokines on CYP enzymes have been shown in cases with rheumatoid arthritis, cancer, and inflammatory bowel disease [13, 20,21]. In rheumatoid arthritis patients with high IL-6 levels, the metabolism of simvastatin (CYP3A4 substrate) is lower. When IL-6 inhibitors are administered these cases, CYP enzyme activity has also been shown to normalize and simvastatin metabolism returns to normal [21]. Anticytokine drugs used in chronic inflammatory diseases such as rheumatoid arthritis, inflammatory bowel disease, and sclerosing dermatitis targeting IL-1, IL-6, and TNF-alpha receptors have a potential risk of decreased clinical effectiveness by directly modulating CYP enzymes while resolving general inflammatory conditions or increasing drug clearance secondary to relieve general inflammation [13]. Ashino et al [59]. found that in a mouse model with rheumatoid arthritis, CYP3A11 mRNA and CYP3A were selectively downregulated to $45 \%$ of the control. Downregulation of the level and activity of CYP3A11 mRNA protein returned with a single dose injection of anti-IL-6 antibodies [59].

In patients with chronic inflammation, administration of IL-6, IL-1, or TNF has been reported to reduce CYP 3A2, 1A1, 2C11, 2C12, and 2E1 enzymatic activities $[13,54,56,57]$. Rendic and Guengerich [20], screened the effects of diseases and environmental factors on the expression and/or activity of human cytochrome P450 (CYP) enzymes and transporters and found that the basic CYP enzymes were modulated in most cancer cases. However, the effects of CYP enzyme modulation on drug metabolism in acute COVID-19 patients and its reflection on their clinical status have not yet been elucidated. It is also estimated that the responses of CYP enzymes to cytokines can be regulated differently in the various stages of inflammation using different mechanisms [14,60]. While the expression of CYP2D, CYP2E1, CYP3A1, and CYP4A was found to decrease to $20 \%$ of the control, CYP2B1 expression decreased to $65 \%$ of the control in an acute rat inflammation model [61]. In acute adenovirus hepatitis in mice, selective downregulation of acetaminophen metabolizing CYP enzymes (CYP1A2 and CYP2E1) resulted in a lower rate of toxic acetaminophen metabolite production and a low risk of acetaminophen hepatotoxicity [62]. In this case, paracetamol was safe in intensive care units. Studies in humans on CYP enzyme modulations under acute infection and inflammation conditions are limited. In the influenza B virus epidemic, as a result of the decrease in CYP1A2 enzyme activity in young children, the metabolism of theophylline, which is the substrate of 
Table 1. İnterections between Cytokines in COVID-19 and Drugs Used to Treat COVID-19

\begin{tabular}{|c|c|c|c|}
\hline Drug name & Metabolization & Drug interactions & $\begin{array}{l}\text { Impact on drug } \\
\text { metabolism and effect }\end{array}$ \\
\hline Chloroquine & CYP2D6 and CYP3A4 & $\begin{array}{l}\text { CYP3A4 inhibitors: } \\
\text { Glucocorticoids, diltiazem, } \\
\text { verapamil, amiodarone, } \\
\text { dronedarone erythromycin, } \\
\text { clarithromycin }\end{array}$ & $\begin{array}{l}\text { Using with CYP3A4 inhibitors, } \\
\text { decrease chloroquine metabolism } \\
\text { and increase the effect of the drug }\end{array}$ \\
\hline Hydroxychloroquine & $\begin{array}{l}\text { CYP2D6, CYP3A4, } \\
\text { CYP3A5, and CYP2C8 }\end{array}$ & $\begin{array}{l}\text { CYP3A4 inhibitors: } \\
\text { Glucocorticoids, diltiazem, } \\
\text { verapamil, amiodarone, } \\
\text { dronedarone erythromycin, } \\
\text { clarithromycin }\end{array}$ & $\begin{array}{l}\text { Using with CYP3A4 inhibitors, } \\
\text { decrease hydroxychloroquine } \\
\text { metabolism and increase the effect } \\
\text { of the drug }\end{array}$ \\
\hline Lopinavir/Ritonavir & $\begin{array}{l}\text { CYP3A4 } \\
\text { CYP2D6 }\end{array}$ & $\begin{array}{l}\text { CYP3A4 inhibitors: } \\
\text { Glucocorticoids, diltiazem, } \\
\text { verapamil, amiodarone, } \\
\text { erythromycin, clarithromycin } \\
\text { CYP3A4 susbtrates: } \\
\text { Decrease the clearence of } \\
\text { amiodaron, diltiazem, } \\
\text { verapamil, midazolam, } \\
\text { corticosteroids erythromycin. }\end{array}$ & $\begin{array}{l}\text { Using with CYP3A4 inhibitors, } \\
\text { decrease lopinavir/ ritonavir } \\
\text { metabolism and increase the effect } \\
\text { of the drug } \\
\text { Using with CYP3A4 substrates, } \\
\text { increase metabolization of the } \\
\text { CYP3A4 substrates }\end{array}$ \\
\hline Favipiravir & Metabolized by oxidases & $\begin{array}{l}\text { Inhibitor of CYP2C8 enzyme. } \\
\text { CYP2C8 substrates: } \\
\text { Amodiaquine } \\
\text { Cerivastatin } \\
\text { Enzalutamide Paclitaxel } \\
\text { Repaglinide } \\
\text { Torasemide } \\
\text { Sorafenib } \\
\text { Rosiglitazone Buprenorphine } \\
\text { Montelukast }\end{array}$ & $\begin{array}{l}\text { Decrease the metabolism of } \\
\text { CYP2C8 substrates. }\end{array}$ \\
\hline $\begin{array}{l}\text { Tocilizumab }{ }^{41 \mathrm{~b}} \\
\text { Anti-IL-6 receptor (IL-6R) } \\
\text { Monoclonal antibody }\end{array}$ & $\begin{array}{l}\text { Nonspecifically } \\
\text { metabolized }\end{array}$ & $\begin{array}{l}\text { TCZ-reversed IL-6 induced } \\
\text { reduction of CYP isozymes. } \\
\text { CYP1A2 } \\
\text { Substrate: } \\
\text { Theophylline, warfarin } \\
\text { CYP2C9 } \\
\text { Substrates: } \\
\text { Ibuprofen, warfarin, ACEI, oral } \\
\text { hypoglycemics } \\
\text { Inhibitors: } \\
\text { Amiodaron } \\
\text { Induction: } \\
\text { Rifampin } \\
\text { CYP2C19 } \\
\text { Substrates: } \\
\text { Benzodiazepines (diazepam, } \\
\text { midazolam), warfarin } \\
\text { CYP3A4 } \\
\text { Substrates: } \\
\text { Cyclosporin, atorvastatin, } \\
\text { simvastatin, calcium channel } \\
\text { blockers (amlodipine, diltiazem, } \\
\text { nifedipine, verapamil) }\end{array}$ & $\begin{array}{l}\text { Using with CYP1A2, CYP2C9, } \\
\text { CYP2C19 and CYP3A4 } \\
\text { substrates, increase metabolization } \\
\text { of tocilizumab } \\
\text { Using with CYP2C9, inhibitors, } \\
\text { decrease drug metabolism and } \\
\text { increase the effect of tocilizumab } \\
\text { Using with CYP2C9, inducers } \\
\text { speed up drug metabolism and } \\
\text { decrease the effect of tocilizumab }\end{array}$ \\
\hline
\end{tabular}




\begin{tabular}{|c|c|c|c|}
\hline $\begin{array}{l}\text { Infliximab } \\
\text { TNF alfa inhibitor } \\
\text { Monoclonal antibody }\end{array}$ & Not available & $\begin{array}{l}\text { CYP2E1 } \\
\text { Substrates: } \\
\text { Acetaminophen, isoflurane, } \\
\text { isoniazid, sevoflurane, } \\
\text { theophylline } \\
\text { İnduction: } \\
\text { Ethanol, isoniazid } \\
\text { İnhibitor: } \\
\text { Amitriptyline, chlorpromazine, } \\
\text { cimetidine } \\
\text { CYP2C19 } \\
\text { Substrates: } \\
\text { Clopidogrel, diazepam, } \\
\text { diphenhydramine, imipramine, } \\
\text { moclobemide, naproxen, } \\
\text { omeprazole, phenobarbital, } \\
\text { phenytoin, propranolol, warfarin } \\
\text { Induction: } \\
\text { Barbiturates,carbamazepine,phe } \\
\text { nytoin,rifampin) } \\
\text { İnhibitors: } \\
\text { Benzylphenobarbital,chloramph } \\
\text { enicol, cimetidine,clopidogrel, } \\
\text { fluconazole, isoniazid, } \\
\text { moclobemide, omeprazole) }\end{array}$ & $\begin{array}{l}\text { Using with CYP2E1 and CYP2C19 } \\
\text { substrates increase metabolization } \\
\text { of inliximab } \\
\text { Using with CYP2E1 and CYP2C19 } \\
\text { inhibitors decrease drug } \\
\text { metabolism and increase the effect } \\
\text { of infliximab } \\
\text { Using with CYP2E1 and CYP2C9 } \\
\text { inducers, speed up drug } \\
\text { metabolism and decrease the effect } \\
\text { of infliximab }\end{array}$ \\
\hline $\begin{array}{l}\text { Corticosteroids } \\
\text { (Methylprednisolone, } \\
\text { dexamethasone and } \\
\text { hydrocortisone }\end{array}$ & CYP3A4 & $\begin{array}{l}\text { CYP3A4 inhibitors } \\
\text { CYP3A4 inducers }\end{array}$ & $\begin{array}{l}\text { Decreased corticosteroid } \\
\text { metabolism when used with } \\
\text { CYP3A4 inhibitors } \\
\text { Speed up drug metabolism and } \\
\text { decrease the effect of } \\
\text { corticosteroids when used with } \\
\text { CYP3A4 inducers. }\end{array}$ \\
\hline
\end{tabular}

CYP1A2, decreased and theophylline toxicity developed [63].

\section{Cytochrome P450 Enzymes and Drug-Drug Interactions of Drugs Used to Treat COVID-19}

Drugs commonly used to treat COVID-19 and their possible interactions with CYP enzymes are discussed on Table1. Cytokine release is expected in acute infection of SARS-CoV-2, as in other infections. Cytokines regulate the metabolism of drugs by changing the expression and activity of drug metabolizing CYP enzymes (Figure 2).

Drugs commonly used to treat COVID-19, their metabolization with CYP enzymes and impact of cytokines are discussed below:

\subsection{Chloroquine $(Q)$ and hydroxychloroquine $(H Q)$}

In addition to its anti-malarial and immunomodulating actions, hydroxychloroquine and has been shown to be effective against SARS-CoV-2 in vitro [64, 65]. Q and $\mathrm{HCQ}$ are viral entry inhibitors. Increasing endosomal $\mathrm{pH}$ required for virus/cell fusion as well as interfering with the glycosylation of cellular receptors of SARS-CoV (ACE-2) are their possible mechanisms of action [66]. Both drugs are complex in terms of pharmacokinetics and pharmacodynamics. Due to their large distribution volumes and strong tissue binding properties, their terminal half-life is prolonged to 1-2 months [67]. The main drug interaction concern with $\mathrm{Q} / \mathrm{HCQ}$ is the prolongation of the QT interval, possibly increasing the risk of arrhythmias or other serious clinical effects. As chloroquine is metabolized by the major enzymes CYP2C8 and CYP3A4/5, the risk of adverse effects is even higher in COVID-19 patients. Hydroxychloroquine is a substrate of CYP2C8, CYP3A4/5, and CYP2D6 enzymes. Depending on the clinical stage, plasma levels of $\mathrm{Q}$ and HQ can reach the toxic range because of the inhibition of CYP enzymes by increased cytokine responses. Hydroxychloroquine itself has also been shown to increase plasma levels of metoprolol metabolized by CYP2D6 [67].

Polymorphism in the CYP enzymes also causes variable drug effects [68]. IL-6, IFN, TNF, TGF, and IL-1 have been shown to downregulate CYP2C8, CYP3A4/5, and CYP2D6 enzymes in human liver cells [14]. Potentially lethal ventricular arrhythmia risk should be predicted in COVID-19 cases with increased uncontrolled cytokine response, as both CQ and HCQ metabolism will 


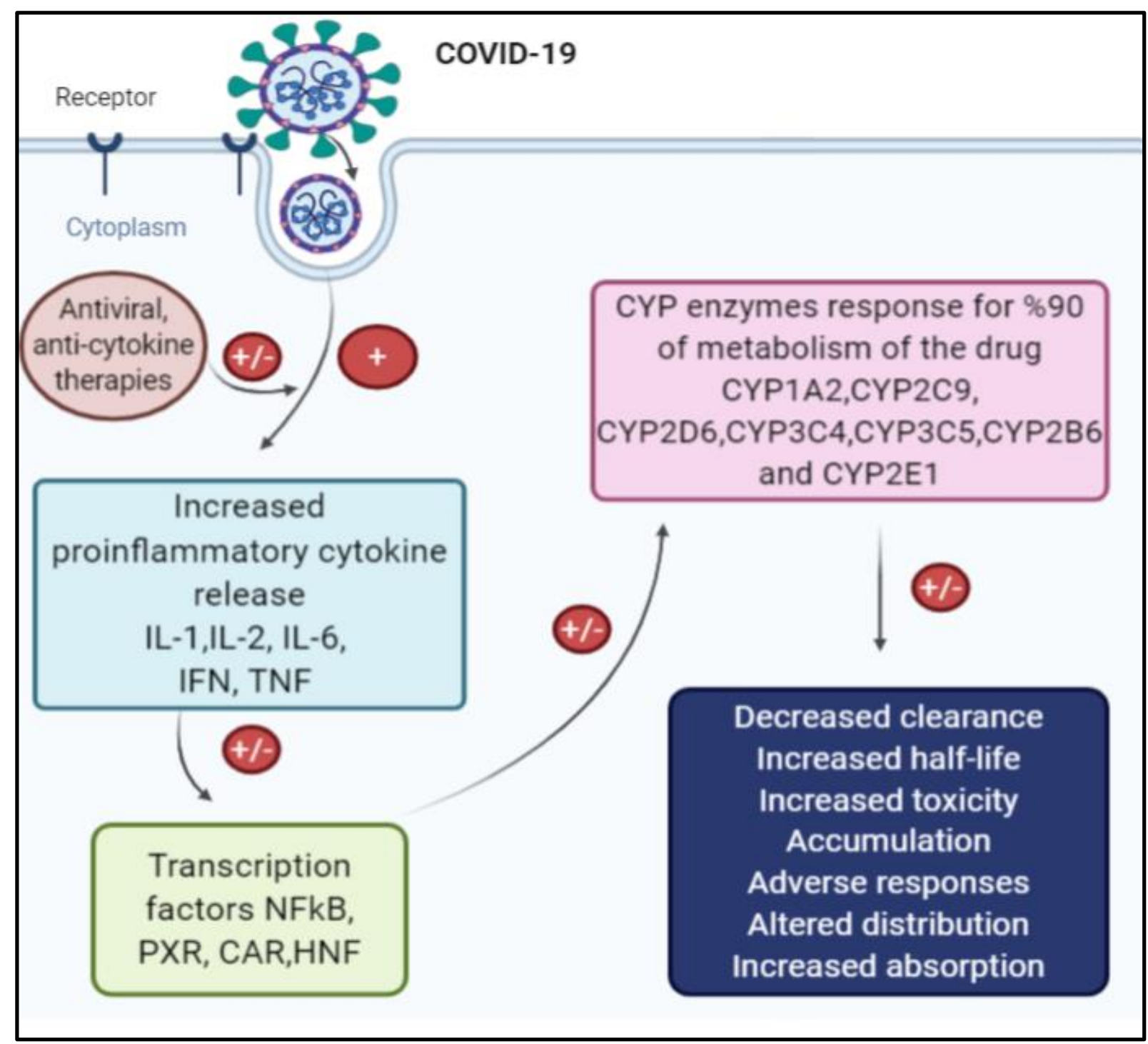

Figure 2. Cytokines affect pharmacokinetics of drugs through regulation of expression and activity of drug metabolizing CYP enzymes in COVID-19.

decrease. Except for cytokines, using other drugs that inhibit CYP450 enzymes in combination with chloroquine and hydroxychloroquine may potentially result in increased blood levels of both chloroquine and hydroxychloroquine. Cimetidine is the most common agent causing increased blood levels of both chloroquine and hydroxychloroquine as a CYP450 enzyme paninhibitor [68].When chloroquine and hydroxychloroquine, inhibitors of CYP2C8 (gemfibrozil and clopidogrel) and inhibitors of CYP 3A4/5 (verapamil, diltiazem, azole anti-fungal agents, most macrolide antibiotics, and ciprofloxacin, among others), are used together, chloroquine and hydroxychloroquine blood levels are possibly elevated. Clinicians should be aware of multiple cardiac side effects such as prolongation of the QT interval, QRS widening, and negative inotropy when using Q or HQ in the transition to the cytokine response period and when used together with these medications. The use of these drugs in combination with other QT-prolonging agents such as amiodarone, methadone, quinolones, tricyclic antidepressants, and anti-emetics (promethazine, haloperidol, droperidol, and ondansetron) may also lead to the development of toxic arrhythmia such as ventricular fibrillation [69]. ECG should be closely monitored for follow-up of QT prolongation in COVID19 cases.

Borba et al [44] found that high-dose CQ, especially in combination with azithromycin and oseltamivir in patients with severe COVID-19, led to a higher mortality rate (39\% vs $15 \%$ ) compared to a low-dose group. In another retrospective observational study, the hospital mortality rate was higher in a group receiving HQ compared to a group not receiving HQ (45). In COVID19 cases, ventricular sensitivity to CQ and HCQ may be due to myocarditis that develops over the course of the disease, the susceptible comorbidity background of COVID-19 patients, cytokine-CYP interactions caused 
by inflammation, or interactions with other QTprolonging drugs.

\subsection{Azithromycin}

Azithromycin is a macrolide anti-bacterial drug. It is a weak substrate for CYP3A4, is minimally metabolized by this enzyme, and neither induces nor inhibits CYP3A4 activity. The interaction of azithromycin with proteins and genetic variances is weak and has activity against gram-negative bacteria [70]. The combination of HCQ and azithromycin is commonly used for COVID-19 treatment. This combination causes additive/synergistic QT prolongation concerns [43].

\subsection{Lopinavir/ritonavir and darunavir/cobicistat}

These are anti-HIV protease inhibitors that inhibit viral protein synthesis. As both lopinavir/ritonavir and darunavir/cobicistat are metabolized by the CYP3A4 enzyme and are also inhibitors of this enzyme, many significant drug interactions can occur. Ritonavir and cobicistat are pharmacologically supportive agents that are used to deliberately inhibit drug metabolism. CYP3A4 substrates can be used in combination with other CYP3A4 drugs (such as amiodarone, diltiazem, verapamil, midazolam, cortisol, and erythromycin), which can accelerate their onset of action, increase blood levels, and cause toxic side effects. When anti-HIV protease inhibitors are combined with CYP3A enzymeinducing rifampicin, corticosteroids, or anti-epileptic drugs (carbamazepine and phenobarbital), the therapeutic blood levels of these drugs may decrease due to increased CYP3A activity (Table 1) [71].

\subsection{Favipiravir}

Favipiravir is an RNA polymerase inhibitor. Drug interactions with favipiravir are minimal or of uncertain clinical significance. In a case report, significant QT prolongation was identified, but this result was suspicious as the patient had other QT interval prolongation risk factors such as encephalitis and central nervous system pathology [72]. Favipiravir is metabolized with Nicotinamide adenine dinucleotide phosphate (NADPH)-independent enzymes and partially by NADPH-dependent enzymes. There are no drug interactions clinically known by CYP450 enzyme-related mechanisms. Favipiravir is also a weak CYP2C8 inhibitor, but clinically significant interactions have not been reported [73].

\subsection{Umifenovir}

Umifenovir exerts its anti-viral effects via both directacting virucidal activity and by inhibiting one (or several) stage(s) of the viral life cycle. Enzymes involved in the metabolism of umifenovir include members of the cytochrome P450 family (primarily CYP3A4) [74].

\subsection{Remdesivir}

Remdesivir (GS-5734) is a viral RNA-dependent RNA polymerase inhibitor. It has been clinically investigated as a broad-spectrum nucleotide analog against coronavirus. There's risk of reduced antiviral activity of remdesivir when used in combination with chloroquine and hydroxychloroquine. Little information is available on its pharmacokinetics (absorption, distribution, metabolism, and elimination). Metabolism of remdesivir to remdesivir triphosphate has been demonstrated in multiple cell types. Data regarding remdesivir overdoses are not readily available [73]. It is difficult to predict whether other drugs affect the pharmacokinetics of remdesivir during COVID-19 therapy or how remdesivir affects the pharmacokinetics of other drugs. In vitro studies have shown that remdesivir is sensitive to CYP3A4-mediated drug interactions, but clinical interactions with CYP3A4 have not been demonstrated [73].

\subsection{Immunomodulating drugs}

Anti-cytokine drugs are used to control the cytokine response in COVID-19. Theoretically, the neutralization of cytokines with anti-cytokine agents is targeted. However, with the activation of CYP enzymes suppressed with cytokines in terms of drug metabolism, an increase in the clearance, a decrease in plasma concentrations, and a decrease in the therapeutic efficacy of CYP enzyme-substrate drugs may be expected [13, 16].

\section{Anakinra}

Anakinra, an IL-1 receptor antagonist (IL-1ra), is a naturally occurring glycoprotein that blocks the binding of IL-1 to IL-1 receptors. Thus, it blocks IL-1-mediated effects. Anakinra is primarily eliminated from the kidneys and its clearance is directly dependent on renal function. Dose adjustment is not recommended in patients with mild and moderate renal impairment. However, in severe renal impairment, dose schedule changes should be made daily [75]. CYP2E1 levels are directly influenced by a variety of cytokines including interferon (IFN)-g, tumor necrosis factor (TNF)-a, and interleukins IL-1b, IL-4, and IL-6. For the most part, cytokines act by altering CYP2E1 gene transcription. However, CYP2E1's role in drug metabolization is low, while it is closely related to ethanol and acetaminophenrelated hepatotoxicity [76].

4.8. Tocilizumab

Tocilizumab (TCZ) is an anti-IL-6 receptor (IL-6R) monoclonal antibody. It binds both membrane binding sites and soluble forms of IL-6R by competitive inhibition, blocking signal transduction pathways [77]. Thus, IL-6 is potentially pleiotropically influenced in other systemic areas such as the immune system (lowering signal transduction to inflammatory mediators that summon $\mathrm{B}$ cells and $\mathrm{T}$ cells), inflammation (lowering production of acute-phase reactants), and bone and blood vessels [39, 77]. It non-specifically metabolizes to peptides and amino acids. TCZ reduces the inhibition of CYP450 enzymes with IL-6 and accelerates the metabolism of drugs metabolized by CYP3A4. Rivaroxaban is a substrate of CYP3A4 and pglycoprotein, and warfarin is a substrate of CYP2B6, CYP2C9, CYP2C19, and CYP3A4. Concomitant use of TCZ may lead to reduced bioavailability of anti- 
coagulants and favor the occurrence of thrombosis [68, 78]. Kim S et al [79] reviewed three clinical and two in vitro studies evaluating the effect of IL-6 and TCZ on CYP activity. In the clinical trials, the bioavailability of simvastatin and omeprazole was found to be decreased by TCZ-induced CYP3A4 activity and CYP2C19 activity, respectively. Aitken et al [14]. showed that the IL-6-induced diminution of CYP2C9 protein levels was greater $(65 \%$ of controls) than that of CYP3A4 $(5 \%$ of controls) in cell cultures. This suggests that CYP2C9 activity may increase to a greater extent than CYP3A4 with TCZ treatment, resulting in increased warfarin metabolism. Clinically, this would result in patients requiring higher doses of warfarin and a possible need for more frequent INR monitoring. In another human hepatocyte culture study, it was shown that TCZ prevented a reduction in CYP3A4 mRNA expression with a less marked reduction in CYP1A2, 2B6, 2C9, 2C19, and 2D6 mRNA led by IL-6. This reduction in mRNA expression level was prevented when TCZ was added to the culture [80].

\subsection{Infliximab (TNF-alpha inhibitor)}

Anti-tumor necrosis factor (anti-TNF) monoclonal antibodies suppress physiological responses to TNFalpha, which is a pro-inflammatory cytokine. It was approved by the FDA to treat autoimmune and immunemediated disorders such as rheumatoid arthritis, ankylosing spondylitis, inflammatory bowel disease, psoriasis, hidradenitis suppurativa, and refractory asthma.

Infliximab is a TNF-alpha inhibiting monoclonal antibody. Others are adalimumab, certolizumab pegol, and golimumab, or with the receptor fusion protein etanercept [35, 40, 81]. The most important and common mechanism of action of TNF-alpha inhibitors is binding to soluble TNF-alpha to neutralize it. TNFs are key inflammatory factors that trigger cytokine storm. Clinical and experimental evidence implicates TNF as a possible mediator of severe immune-based pulmonary injury that can follow infection with H5N1 influenza and SARS coronavirus [35].

Inflammatory bowel disease patients with COVID-19 on anti-TNF therapy were no worse than those receiving sulfasalazine/mesalamine when compared in terms of hospital requirement and mortality rates of other drugs, but there are insufficient data to draw conclusions about better outcomes [41]. As with other monoclonal antibodies, infliximab is predicted to be non-specifically metabolized to peptides and amino acids that can be reused in the body for de novo synthesis of proteins or excretion by the kidney [82]. Its metabolism is not affected by CYP enzymes. However, TNF-alpha is an enzyme inhibitor of CYP2E1 [54, 83] and CYP2C19 [83]. The toxicological potential of infliximab in humans has not yet been fully established. The metabolism of warfarin can be increased when combined with infliximab [73].

4.10. Other immunomodulators

\subsubsection{Tadekinig alpha}

This is a recombinant human interleukin-18 binding protein (IL-18BP). Phase I trials of the drug have been conducted with healthy volunteers and psoriasis and rheumatoid arthritis patients. IL-18 is a pro-inflammatory cytokine of the IL-1 family produced by various cell types, including monocytes/macrophages [84]. The biological activity of IL-18 is very tightly controlled by IL-18 binding protein (IL-18BP). IL-18BP is a naturally occurring protein that inhibits IL-18 by binding with high affinity. In adult-onset Still's disease, tadekinig alpha (IL18BP) was found to be safe and effective [85]. Although blocking IL-18 may be related to COVID-19, there is no clinical evidence or any recorded randomized controlled trials assessing the safety and efficacy of IL-18BP [42]. CYP2C18 is expressed by IL 18 at very low levels. Therefore, drug interactions due to changes in CYP enzyme activity are not expected in COVID-19 patients. 4.10.2. IFN-alpha and beta

These are also widely used for COVID-19 treatment in combination with QC, HCQ, and/or anti-viral agents due to their anti-viral effects. They have been reported to be effective at lowering CRP and IL-6 levels, reducing virus clearance, improving clinical conditions such as pneumonia, and increasing survival rates [40, 86, 87]. No change in their metabolism is expected during COVID-19 treatment. However, as it is known that IFNalpha [83] and IFN-gamma [54] as cytokines regulate CYP1A2 and CYP2E1 enzymes, combined use with substrates, inducers, and inhibitors of these enzymes should be done cautiously (Table 1).

4.10.3. Janus kinase (JAK) inhibitors (ruxolitinib and baricitinib)

JAK inhibitors could potentially affect both inflammation and cellular viral entry in COVID-19 cases [88]. Ruxolitinib and baricitinib inhibit the downstream IFN-g pathway targeting the JAK kinase receptor. They inhibit JAK1- and JAK2-mediated cytokine release. They are FDA-approved drugs for the treatment of myelofibrosis, polycythemia vera, and graft-versus-host disease. In COVID-19 cases, they are used in conjunction with anti-viral therapy to decrease hyperinflammation caused by the virus to prevent lung damage and cytokine storm and reduce ICU admission rates. There are minimal interactions with CYP enzymes [89].

\subsubsection{Corticosteroids}

Corticosteroids are a class of steroid hormones that have anti-inflammatory functions. The early administration of glucocorticoids inhibits the initiation of the body's immune defense mechanism, thereby increasing viral loads and ultimately leading to secondary infection and other adverse consequences. Therefore, because of these concerns, glucocorticoids are mainly used in critically ill patients suffering inflammatory cytokine storms. In the treatment of COVID-19, methylprednisolone, dexamethasone, and hydrocortisone were used in conjunction with $\mathrm{Q}, \mathrm{HQ}$, and/or anti-viral therapy. The effects of corticosteroids on clinical and laboratory 
improvement, decreasing the ventilator requirement rate, and decreasing the rate of staying on ventilators were investigated. Meta-analyses showed that early and short courses (3-5 days) of methylprednisolone (methylprednisolone i.v. 0.5 to $2 \mathrm{mg} / \mathrm{kg} / \mathrm{day}$ ) in patients with moderate to severe COVID-19 reduced escalation of care and improved clinical outcomes [37, 38]. Other studies reported that they lead to higher mortality and higher rates of bacterial infection and hypokalemia [36, 90]. Methylprednisolone is the corticosteroid of choice primarily because of its median effect with a half-life of 12-36 hours and better immunosuppression intensity. The Randomized Evaluation of COVid-19 thERapY (RECOVERY) trial showed that low-dose dexamethasone $(6 \mathrm{mg}$ once per day, peroral or intravenously) significantly reduced deaths of ventilated patients and those receiving oxygen only [91]. Treatment success with low-dose dexamethasone may be due to the prevention of the expected corticosteroid overdose. Corticosteroids are metabolized by CYP3A4. In COVID-19 cases, corticosteroid overdose should be expected due to this enzyme inhibition. However, it should be kept in mind that cortisol's metabolism is much slower when imidazole, anti-fungals, ritonavir, calciumchannel blockers, and amiodarone, which are CYP3A4 inhibitors, are used together in this period (Table 1). In COVID-19 cases with mild respiratory failure, when systemic corticosteroids are not required, it may be more appropriate to reach the target area with inhalation at low doses. Beclomethasone is hydrolyzed and not metabolized via cytochrome P450, so it is preferred in mild to moderate COVID-19 cases receiving CYP3A4 inhibitors [92, 93].

\section{Conclusion and Recommendations}

The novel coronavirus (SARS-CoV-2) and host cell interactions lead to the production of very strong immune mediators. Depending on the effects of cytokines on CYP450 enzymes in the liver and other organs, there may be interactions, especially pharmacokinetically, with CYP enzymes at the metabolism level. These cytokinedrug and drug-drug interactions may cause toxic drug effects and an insufficient therapeutic response. Among the drugs used to treat COVID-19, chloroquine/hydroxychloroquine, tocilizumab, and corticosteroids seem to be affected by cytokine storms and can cause drug interactions and adverse effects. Unfortunately, in our clinical practice, the available information does not allow the optimization of drugs dosages with CYP450 enzyme substrates to be determined before treatment following the individual's specific conditions. Therefore, the treatment approach is continued with repeated dose adjustments based on the baseline dose calculations according to the plasma levels and clinical response. In COVID-19 cases, monitoring the clinical effectiveness of drugs or blood levels to avoid potential drug interactions caused by cytokine responses induced by the nature of the disease will prevent adverse and toxic effects and/or inadequate treatment and increase the effectiveness of treatment. Thus, the clinician's foresight and the fact that clinical pharmacologists are actively involved in treatment strategies in intensive treatment protocols will contribute to this process.

\section{References}

1. World Health Organization (2020). Naming the coronavirus disease (COVID-19) and the virus that causes it. https://www.who.int/emergencies/diseases/novel-coronavirus2019/technical-guidance/naming-the-coronavirus-disease-(covid2019)-and-the-virus-that-causes-it (accessed 21 January 2021).

2. Prajapat, M, Sarma, P, Shekhar, N, et al. Drug targets for corona virus: A systematic review, Indian Journal of Pharmacology 2020; 52: 56-65.

3. Kazak, A, Hintistan, S, Önal, B. COVID-19 Vaccine Development Studies in the World and Turkey, Celal Bayar University-Health Sciences Institute Journal, 2020, 7, 571-575.

4. Wang, F, Nie, J, Wang, H, et al. Characteristics of peripheral lymphocyte subset alteration in COVID-19 pneumonia, The Journal of Infectious Diseases, 2020, 221; 1762-1769.

5. Mehta, P, McAuley, D, F, Brown, M, Sanchez, E, Tattersall, R, S, Manson, J, J, H, L, H, Acros Speciality Collaboration, COVID-19: consider cytokine storm syndromes and İmmunosuppression, The Lancet, 2020, 395, 1034-1035.

6. Li, G, Fan, Y, Lai, Y, et al. Coronavirus infections and immune responses, Journal of Medical Viroogy, 2020, 92, 424-432.

7. Mc Gonagle, D, Sharif, K, O'Regan, A, Brigewood, C, Interleukin6 use in COVID-19 pneumonia related macrophage activation syndrome, Autoimmunity Reviews, 2020: 19, 102537.

8. Sen, E, S, Ramanan, A, V, Cytokine Storm Syndrome Associated with Hemorrhagic Fever and Other Viruses, in: R, O, Cron, E, M, Behrens, (Eds), Cytokine Storm Syndrome. Springer Nature Switzerland AG, 2019, 277-298.

9. Huang, C, Wang, Y, Li, X, et al. Clinical features of patients infected with 2019 novel coronavirus in Wuhan, China, Lancet London England, 2020, 395, 497-506.

10. $\mathrm{Li}, \mathrm{H}$, Xiang, X, Ren, H, et al. Serum Amyloid A is a biomarker to distinguish the severity and prognosis of Coronavirus Disease 2019 (COVID-19), The Journal of Infection, 2020, 80, 646-655.

11. Stavropoulou, E, Pircalabioru, G, G, Bezirtzoglou, E. The Role of Cytochromes P450 in infection, Frontiers in Immunology, 2018, 31, 89.

12. Goralski, K, B, Ladda, A, M, O McNeil, J, Drug-Cytokine Interactions, in: Georgiev V, Pai MP, Kiser, J.J, Gubbins, P.O and Rodvold, K.A (Eds), Drug Interactions in Infectious Diseases: Mechanisms and Models of Drug Interactions, Switzerland, Springer International Publishing, 2018, 163-204.

13. Morgan, E, T, Impact of infectious and inflammatory disease on cytochrome P450-mediated drug metabolism and pharmacokinetics. Clinical Pharmacology and Therapeutics, 2009, 85, 434 - 438.

14. Aitken, A.E, Morgan, E.T, Gene-Specific Effects of Inflammatory Cytokines on Cytochrome P4502C, 2B6 and 3A4 mRNA Levels in Human Hepatocytes, Drug Metabolism \& Disposition, 2007, 35, $1687-1693$.

15. Aitken, A, Richardson, T.A, Morgan, E.T, Regulation of drugmetabolizing enzymes and transporters in inflammation, Annual Review of Pharmacology and Toxicology, 2006, 46, 123-149.

16. Bleau, A, M, Maurel, P, Pichette, V, Interleukin-1beta, interleukin-6, tumour necrosis factor-alpha and interferon-gamma released by a viral infection and an aseptic inflammation reduce YP1A1, $1 \mathrm{~A} 2$ and 3A6 expression in rabbit hepatocytes. European Journal of Pharmacology, 2003, 473,197-206.

17. Renton, K.W, Cytokines and Pharmacokinetic Drug Interactions. In House RV and Descotes J (Eds): Cytokines in Human Health: Immunotoxicology, Pathology, and Therapeutic Applications, Humana Press Inc., Totowa, NJ, USA, 2007, 275-296.

18. Haas, C, E. Drug-Cytokine Interactions, in: Piscitelli SC and Rodvold KA (Eds), Drug Interactions in Infectious Diseases. Humana Press Inc. Totowa, New Jersey, USA, 2001, pp 287-310

19. Dickmann, L.J, Patel, S.K, Rock, D.A, Wienkers, L.C, Slatter, J.G, Effects of interleukin-6 (IL-6) and an anti-IL-6monoclonal antibody 
on drug-metabolizing enzymes in human hepatocyte culture, Drug Metabolism \& Disposition, 2011, 39, 1415-1422.

20. Rendic, S, Guengerich, F.P, Update information on drug metabolism systems-2009, part II: summary of information on the effects of diseases and environmental factors on human cytochrome P450 (CYP) enzymes and trans-porters, Current Drug Metabolism, 2010, $11,4-84$.

21. Schmitt, C, Kuhn, B, Zhang, X, Kivitz, A.J, Grange, S, DiseaseDrug-Drug Interaction Involving Tocilizumab and Simvastatin in Patients With Rheumatoid Arthritis, Clinical Pharmacology \& Therapeutics, 2011, 89, 735-740.

22. Vial, T, Descotes, J. Clinical Adverse Effects of Cytokines on the Immune System, in: House RV, Descotes J. (Eds), Cytokines in Human Health: Immunotoxicology, Pathology, and Therapeutic Applications, Humana Press Inc., Totowa, NJ, USA, 2007, 319-349.

23.. Siddiqi, H.K, Mehra, M.R, COVID-19 illness in native and immunosuppressed states: A clinical-therapeutic staging proposal, Journal of Heart and Lung Transplantation, 39 (2020) 405-407.

24. Mahmudpour, M, Roozbeh, J, Keshavarz, M, Farrokhi, S, Nabipour, I. COVID-19 cytokine storm: The anger of inflammation, Cytokine 2020, 133, 1551512

25. Chen, Z, Hu, J, Zhang, Z, et al. Efficacy of hydroxychloroquine in patients with COVID-19: results of a randomized clinical trial, medRxiv.

2020 , https://www.medrxiv.org/content/10.1101/2020.03.22.20040758v3

26. Gautret, P, Lagier, J.C, Parola, P, et al, Hydroxychloroquine an azithromycin as a treatment of COVID-19: results of an open-label non-randomized clinical trial, International Journal of Antimicrobial Agents, 2020, 56, 105949.

27. Molina, J.M, Delaugerre, C, Le, Goff J, Mela-Lima, B, Ponscarme D, Goldwirt, L, de Castro N, No evidence of rapid antivira clearance or clinical benefit with the combination of hydroxychloroquine and azithromycin in patients with severe COVID-19 infection, Médecine et Maladies Infectieuses, 2020, 50, 384.

28. Zhang, G, Hu, C, Luo, L, Fang, F, Chen, Y, Li, J, et al. Clinica features and outcomes of 221 patients with COVID-19 in Wuhan, China, medRxiv https://www.medrxiv.org/content/10.1101/2020.03.02.20030452v1

29. Wang, Y, Zhang, D, Du, G, Du, R, Zhao, J, Jin, Y, et al, Remdesivir in adults with severe COVID-19: a randomised, double-blind, placebo-controlled, multicentre trial, The Lancet, 2020, 395, 15691578.

30. Chen, C, Zhang, Y, Huang, J, Yin, P, Cheng, Z, Wu, J, et al, Favipiravir versus Arbidol for COVID-19: A Randomized Clinical Trial, medRxiv. https://www.medrxiv.org/content/10.1101/2020.03.17.20037432v4

31. Costanzo, M, de Giglio,, M, Roviello G.N, SARS-CoV-2: Recent Reports on Antiviral Therapies Based on Lopinavir/Ritonavir, Darunavir/Umifenovir, Hydroxychloroquine, Remdesivir Favipiravir and Other Drugs for the Treatment of the New Coronavirus, Current Medicinal Chemistry, 2020, 27, 4536-4541.

32. Gattinoni, L, Chiumello, D, Caironi, P, Busana, M, Romitti, F, Brazzi, L, Camporota,L, COVID-19 pneumonia: different respiratory treatment for different phenotypes? Intensive Care Medicine, 2020, 46,1099-1102.

33. COVID-19 Treatment Guidelines Panel. Coronavirus Disease 2019 (COVID-19) Treatment Guidelines. National Institutes of Health, https://covid19treatmentguidelines.nih.gov/. (Last updated July 30 2020)

34. COVID-19 Adult Treatment Guidelines. Coronavirus Disease 2019 (COVID-19) https://covid19bilgi.saglik.gov.tr/depo/algoritmalar/COVID19PLKACILHASTAYONETIMI.pdf.

35. Russell, B, Moss, C, George, G, Santaolalla, A, Cope A, Papa S, Van Hemelrijck M, Associations between immune-suppressive and stimulating drugs and novel COVID-19-a systematic review of current evidence, ecancer. 2020, 14, 1022.

36. Yang, Z, Liu, J, Zhou, Y, Zhao, X, Zhao, Q, Liu J, The effect of corticosteroid treatment on patients with coronavirus infection: a systematic review and meta-analysis, Journal of Infection, 81 (2020) e13-e20.

37. Wang, Y, Jiang, W, He, Q, Wang, C, Liu, B, Zhou, P, Dong, N, Tong, Q, Early, low-dose and short-term application of corticosteroid treatment in patients with severe COVID-19 pneumonia: singlecenter experience from Wuhan, China. MedRxiv, 2020.
38. Fadel, R, Morrison, AR, Vahia, A, et al. COVID-19 Management Task Force, Early Short Course Corticosteroids in Hospitalized Patients with COVID-19, Clinical Infectious Diseases 2020, 71(16), 2114-2120.

39. $\mathrm{Fu}, \mathrm{B}, \mathrm{Xu}, \mathrm{X}, \mathrm{Wei}, \mathrm{H}$, Why tocilizumab could be an effective treatment for severe COVID-19, Journal of Translational Medicine, 2020, 18, 164

40. Ye, Q, Wang, B, Mao, J. The pathogenesis and treatment of the 'Cytokine Storm' in COVID-19, Journal of Infection, 2020, 80, $607-$ 613

41. Feldmann, M, Maini, R, N, Woody, J, N, et al, Trials of anti-tumour necrosis factor therapy for COVID-19 are urgently needed, The Lancet, 2020, 395, 1407-1409.

42. Jamilloux, Y, Henry, T, Belot, A, et al. Should we stimulate or suppress immune responses in COVID-19? Cytokine and anticytokine interventions, Autoimmunity Reviews, 2020, 19, 102567.

43. Chorin, E, Dai, M, Shulman, E, et al, The QT interval in patients with COVID-19 treated with hydroxychloroquine and azithromycin, medRxiv 2020.04.02.20047050.

44. Borba, M, G, S, Val, F, F, A, Sampaio, V, S, et al, Effect of high vs low doses of chloroquine diphosphate as adjunctive therapy for patients hospitalized with severe acute respiratory syndrome coronavirus 2 (SARS-CoV-2) infection: a randomized clinical trial, JAMA, 2020, 3, e208857.

45. Magagnoli, J, Narendran, S, Pereira, F, et al., Outcomes of hydroxychloroquine usage in United States veterans hospitalized with Covid-19, medRxiv, 2020.

46. Kany, S, Vollrath, J.T, Relja, B. Cytokines in Inflammatory Disease The International Journal of Molecular Sciences, 2019, 20, 6008.

47. Cressman, A.M, Petrovic, V, Piquette-Miller, M. Inflammationmediated changes in drug transporter expression/activity: implications for therapeutic drug response, Expert Review of Clinical Pharmacology, 2012, 5, 69-89.

48. Petrovic, V, Teng, S, Piquette-Miller, M. Regulation of drug transporters during infection and inflammation, Molecular Intervention 2007, 7, 99- 111.

49. Heemskerk, S, Peters, J.G.P, Louisse, J, Sagar, S, Russel, F.G.M, Masereeuw, R. Regulation of P-glycoprotein in renal proximal tubule epithelial cells by LPS and TNF-alpha, Journal of Biomedical and Biotechnology, 2010, 525180.

50. Bezirtzoglou, E, Intestinal cytochromes $\mathrm{P} 450$ regulating the intestina micro-biota and its probiotic profile, Microbial Ecology in Health Disease, 2012, 23, 1-10.

51. Clark, E.S, Jones, B.C, Human cytochromes P450 and their role in metabolism based drug-drug interaction, in: Rodrigues A, D (Ed), Drug-Drug Interactions: Drugs and the Pharmaceutical Sciences, Marcel Dekker, New York, USA, 2002, pp. 55-88.

52. Chang, K.C, Bell, T.D, Lauer, B.A, Chai, H. Altered Theophylline Pharmacokinetics During Acute Respiratory Viral Illness, The Lancet 1978, 27, 1132-1133.

53. Renton, KW, Knickle, LC. Regulation of cytochrome P450 during infectious disease. Can Journal of Physiology and Pharmacology, 1990, 68, 777-781.

54. Overton, C, L, Hudder, A, Novak, R, F. The CYP2E Subfamily, in: Ioannides C (Ed), Cytochromes P450. Role in the Metabolism and Toxicity of Drugs and other Xenobiotics. RSC Publishing, Cambridge, UK, 2008, pp. 282.

55. Zhou, J, Li, F. Potential pharmacokinetic interactions of therapeutic cytokines or cytokine modulators on small-molecule drugs: mechanistic understanding via studies using in vitro systems. Drug Metabolism and Drug Interactions, 2014, 29, 17-28.

56. Tufan, A, Avanoğlu, Güler, A, Matucc1-Cerınıc, M. COVID-19, immune system response, hyper inflammation and repurposing antirheumatic drugs. Turkish Journal of Medical Science, 2020, 50, 620-632.

57. Sanaee, F, Clements, J, D, Waugh, A, W, G, Fedorak, R, N, Lewanczuk, R, Jamali, F. Drug-disease interaction: Crohn's disease elevates verapamil plasma concentrations but reduces response to the drug proportional to disease activity, British Journal of Clinical Pharmacology, 2011, 72, 787-797.

58. Tapner, M, Liddle, C, Goodwin, B, George, J, Farrell, G,C Interferon gamma down-regulates cytochrome $\mathrm{P} 450$ 3A genes in primary cultures of well-differentiated rat hepatocytes, Hepatology, 1996, 24, 367-373.

59. Ashino, T, Arima, Y, Shioda, S, Iwakura, Y, Numazawa, S, Yoshida, T. Effect of interleukin-6 neutralization on cyp3a11 and 
metallothionein-1/2 expressions in arthritic mouse liver, European Journal of Pharmacology, 2007, 558, 199-207.

60. Frye, R, F, Zgheib, N, K, Matzke, G, R, et al, Liver disease selectively modulates cytochrome P450--mediated metabolism, Clinical Pharmacology and Therapeutics, 2006, 80, 235-245.

61. Muntanı, J, Longo, V, Mitjavila, M, T, Gervası, P.G, IngelmanSundberg M. Effect of carrageenan-induced granuloma on hepatic cytochrome P-450 isozymes in rats, Inflammation, 1995, 19, 143156.

62. Getachew, Y, James, L, Lee, W.M, Thiele, D.L, Miller B.C Susceptibility to acetamino-phen (APAP) toxicity unexpectedly is decreased during acute viral hepatitis in mice, Biochemical Pharmacology, 2010, 79, 1363-1371.

63. Kraemer, M.J, Furukawa C.T, Koup J.R, Shapiro, G.G, Pierson, W, E, Bierman, C.W, Altered Theophylline Clearance During an Influenza B Outbreak, Pediatrics, 1982, 69, 476-80.

64. Liu, J, Cao, R, Xu, M, et al, Hydroxychloroquine, a less toxic derivative of chloroquine, is effective in inhibiting SARS-CoV-2 infection in vitro, Cell Discovery, 2020, 6, 16

65. Keyaerts, E, Vijgen, L, Maes, P, Neyts, J, van Ranst, M, In vitro inhibition of severe acute respiratory syndrome coronavirus by chloroquine, Biochemical and Biophysical Research Communications, 2004, 323, 264-268.

66. Yavuz, S.S, Ünal, S, Antiviral treatment of COVID-19, Turkish Journal of Medical Science, 2020, 50, 611-619.

67. Albertson, T.E, Chloroquine and Other Aminoquinolines, in: Olson KR (Ed), Poisoning \& Drug Overdose. McGraw-Hill Education, 2018, 194-196.

68. Lee, J.Y, Vinayagamoorthy, N, Han, K, et al, Association of polymorphisms of cytochrome P450 2D6 with blood hydroxychloroquine levels in patients with systemic lupus erythematosus. Arthritis and Rhematology, 2016, 68, 184-190.

69. Wisniowska, B, Tylutki, Z, Wyszogrodzka, G, Polak, S. Drug-drug interactions and QT prolongation as a commonly assessed cardiac effect- comprehensive overview of clinical trials, $B M C$ Pharmacology and Toxicology, 2016, 17, 12.

70. Fohnera, A.E, Sparreboomb, A, Altmana, R.B, Klein, T.E, Pharm GKB summary: macrolide antibiotic pathway, pharmacokinetics/pharmacodynamics, Pharmacogenet Genomics. 2017, 27, 164-167.

71. Faragon, J.J, Jehan, Z, Budak, J.Z, Drug Interactions with Antiretroviral Medications. C National HIV in Curriculum Section 3: Antiretroviral Therapy, https://www.hiv.uw.edu/go/antiretroviraltherapy/drug-drug-interactions/core-concept/all.

72. Chinello, P, Petrosillo, N, Pittalis, S, Biava, G, Ippolito, G, Nicastri, $\mathrm{E}$, on behalf of the INMI Ebola Team, QTc interval prolongation during favipiravir therapy in an Ebolavirus-infected patient, PLOS Neglected Tropical Diseases, 2017, 11(12), e0006034.

73. https://www.micromedexsolutions.com/micromedex2/librarian Accessed July 2, 2020

74. Brown, K.C, Paul, S, Kashuba, A.D, Drug interactions with new and investigational antiretrovirals, Clinical Pharmacokinetics, 2009, 48, 211-241.

75. Yang, B, B, Baughman, S, Sullivan, J.T, Pharmacokinetics of anakinra in subjects with different levels of renal function, International Journal of Clinical Pharmacology and Therapeutics, 2003, 74, 85-94.

76. Pelkonen, O, Turpeinen, M, Hakkola, J, Honkakoski, P, Hukkanen, $\mathrm{J}$, Raunio, H. Inhibition and induction of human cytochrome P450 enzymes: current status, Archives of Toxicology, 2008, 82, 667-715.

77. Zhang, X, Peck, R. Clinical pharmacology of tocilizumab for the treatment of patients with rheumatoid arthritis. Expert Review of Clinical Pharmacolology, 2011, 4, 539-558.

78. Clarivet, B, Robin, P, Pers, Y.M, et al, Tocilizumab and mesenteric arterial thrombosis: drug-drug interaction with anticoagulants metabolized by CYP 450 and/or by P-glycoprotein, European Journal of Clinical Pharmacology, 2016, 72, 1413-1414.

79. Kim, S, Östör, A.J.K, Nisar, M.K, Interleukin-6 and cytochromeP450, reason for concern? Rheumatolology International, 2012, 32 2601-2604

80. Zhang, X, Schmitt, C, Grange, S, et al. Disease-drug interaction studies of tocilizumab with cytochrome $\mathrm{P} 450$ substrates in vitro and in vivo. Clinical Pharmacolology and Therapeutics, 2009, 85, S59.
81. Papamichael, K, van Stappen, T, Jairath V, et al, Review article: Pharmacological aspects of anti-TNF biosimilars in inflammatory bowel diseases, Alimentary Pharmacology and Therapeutics, 2015, 42, 1158-1169.

82. Danese, S, Sans, M, Scaldaferri, F, et al, TNF-alpha blockade downregulates the CD40/CD40L pathway in the mucosal microcirculation: a novel anti-inflammatory mechanism of infliximab in Crohn's disease, The Journal of Immunology, 2006, 176, 2617-2624.

83. Lee, J.I, Zhang, L, Men, A.Y, Kenna, L.A, Huang, S.M, CYPMediated Therapeutic Protein-Drug Interactions Clinical Findings, Proposed Mechanisms and Regulatory Implications, Clinical Pharmacokinetics, 2010, 49, 295-310.

84. Dinarello, C.A, Novick, D, Kim, S. Interleukin-18 and IL-18 binding protein, The Frontiers in Immunology, 2013, 4, 289.

85. Gabay, C, Fautrel, B, Rech, J, et al. Open-label, multicentre, doseescalating phase II clinical trial on the safety and efficacy of tadekinig alfa (IL-18BP) in adult-onset Still's disease, Annals of Rheumatologic Disease, 2018, 77, 840-847.

86. Sanders, J.M, Monogue, M.L, Jodlowski, T.Z, Cutrell J.B, Pharmacologic Treatments for Coronavirus Disease, 2019, (COVID19), A Review, JAMA 2020, 323, 1824-1836.

87. Zhou, Q, Chen, V, Shannon, C.P, et al, Interferon-a2b Treatment for COVID-19, The Frontiers in Immunology, 11, 1061.

88. Caocci, G, La Nasa, G, Could ruxolitinib be effective in patients with COVID-19 infection at risk of acute respiratory distress syndrome (ARDS)? Annals of Hematology, 2020, 14, 1-2

89. Stebbing, J, Phelan, A, Griffin, I, Tucker, C, Oechsle, O, Smith, D, Richardson, P. COVID-19: combining antiviral and antiinflammatory treatments, Lancet Infectious Diseases, 2020, 20, 400 402.

90. Russell, C.D, Millar, J.E, Baillie, J.K, Clinical evidence does not support corticosteroid treatment for 2019-nCoV lung injury, The Lancet, 2020, 395, 473-475.

91. Low-cost dexamethasone reduces death by up to one third in hospitalised patients with severe respiratory complications of COVID-19. Published 16 June, 2020 https://www.ox.ac.uk/news/2020-06-16-low-cost-dexamethasonereduces-death-one-third-hospitalised-patients-severe

92. Daveluy, A, Raignoux, C, Miremont-Salamé G, et al, Drug interactions between inhaled corticosteroids and enzymatic inhibitors, European Journal of Clinical Pharmacology, 2009, 65, $743-745$.

93. Features of 20133 UK patients in hospital with covid-19 using the ISARIC WHO Clinical Characterisation Protocol: prospective observational cohort study, British Medical Journal, 2020, 369, m1985

http://edergi.cbu.edu.tr/ojs/index.php/cbusbed isimli yazarın CBU-SBED başlıklı eseri bu Creative Commons Alıntı-Gayriticari4.0 Uluslararası Lisansı ile lisanslanmıștır.

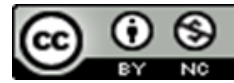

